\title{
Metaphors for Solitary Confinement in Notes from Underground and Notes from the House of the Dead
}

\author{
Carol Apollonio
}

1. "They were almost obliterated socially. They became permanently withdrawn, and they lived as outcasts - regularly set upon, as if inviting abuse."

2. They "lose the ability to initiate behavior of any kind - to organize their own lives around activity and purpose. Chronic apathy, lethargy, depression, and despair often result.... They have difficulties with 'irrational anger.' Many ... become consumed with revenge fantasies."

3. "He observed himself becoming neurotically possessive about his little space, at times putting his life in jeopardy by flying into a rage if a guard happened to step on his bed. He brooded incessantly, thinking back on all the mistakes he'd made in life, his regrets, his offenses against God and family" (about Terry Anderson's experience of solitary confinement as a hostage of Hezbollah in Lebanon). ${ }^{3}$

4 "Paranoia, aggressive fantasies, and impulse control problems ..."4

1 Atul Gawande, “Hellhole," The New Yorker, March 30, 2009, 36.

2 Ibid., 40.

3 Ibid., 38.

4 Rick Raemisch, "My Night in Solitary," New York Times, February 21, 2014, A23. 
The reader of Dostoevsky's Notes from Underground (1864) would be forgiven for assuming that these observations concern the work's misanthropic hero. He too is withdrawn, depressed, neurotic, emotional, vengeful, irrational, angry, regretful, and brooding. The story he tells about his encounter with the prostitute Liza is precisely a tale of, as quote number 3 puts it, "mistakes he'd made in life, regrets, and offenses." Yet the referents here are not fictional characters but real-life subjects of experiments-inside and outside the lab. The socially inept, withdrawn creatures described in the first quote are rhesus monkeys raised without their mothers in psychology professor Harry Harlow's Wisconsin lab in the 1950s. Though the monkeys' basic physical needs were met, the absence of a living caregiver led to profound psychological and emotional disturbances. They were the first scientifically studied sufferers of what is now known as reactive attachment disorder, a syndrome diagnosed in children, whose symptoms include the following:

persistent failure to initiate or respond in a developmentally appropriate fashion to most social interactions, as manifest by excessively inhibited, hypervigilant, or highly ambivalent and contradictory responses (e.g., the child may respond to caregivers with a mixture of approach, avoidance, and resistance to comforting, or may exhibit frozen watchfulness)."

A similar experiment (though inadvertent) was conducted on the so-called Romanian orphans who emerged profoundly disturbed from behind the Iron Curtain in the early 1990s. These children had also been raised in institutional settings without loving caregivers. ${ }^{6}$

The subjects described in the other quotes are convicts or hostages held in solitary confinement. As physician and writer Atul Gawande shows, in all these cases-monkeys, orphans, prisoners - the psychological effects are similar and suggest manifestations of the same underlying problem. Psychologists and specialists in penology offer a precise and, in fact, obvious explanation for this

5 "Diagnostic Criteria for 313.89 Reactive Attachment Disorder of Infancy or Early Childhood," BehaveNet, accessed February 22, 2016, http://behavenet.com/node/21499.

6 For one overview, see Felicia Iftene and Nasreen Roberts, "Romanian Adolescents: Literature Review and Psychiatric Presentation of Romanian Adolescents Adopted in Romania and in Canada," Journal of the Canadian Academy of Child and Adolescent Psychiatry 13, no. 4 (2004): 110-13, accessed February 22, 2016, http://www.ncbi.nlm.nih.gov/pmc/articles/ PMC2538707/. 
cluster of behavior patterns: an absence of loving contact with members of their own species. In the case of the monkeys, the results were so egregious that they led to a new ethical code, forbidding researchers to treat lab animals this way. When human beings (children, prisoners) are subjected to similar conditions, the issue gets very complicated. In the present day, social workers are overwhelmed as they try to care for unloved children, and tens of thousands of convicts are held in isolation units. ${ }^{7}$

There is a great gulf in time and space between these subjects and Dostoevsky's disturbed hero, not to mention the ontological differences: they are "real," nonfictional creatures subjected to analysis via "-ologies"- psychology, sociology, criminology, penology, statistics. He, or "it," is a purely fictional creation and as such requires specialized analytical approaches that move beyond those of the social sciences. The Underground Man clearly manifests symptoms of reactive attachment disorder, but the real question is, in the words of Oblomov, "Why am I the way I am?" Exploring this question will lead into the hero's back story, into the historical context within which he was created, and into a deeper question about the human condition: "Why is the I the way it is?" Our exploration leads to the paradox of what any of this has to do with prison and with solitary confinement, in particular. Even the most casual reader will note that the Underground Man is not in prison. And there are lots of people around, so he's not solitary either. To get to the bottom of this we need to read the book as literature, subjecting these obvious facts to a metaphorical reading in which Dostoevsky presents an abstract problem (that of the ego and the nature of its freedom) using tropes of spatial confinement. We will start with some easy truths. I offer three sequential lines of analysis, on an increasing scale of complexity:

1. Debates on punishment and solitary confinement in Dostoevsky's time

2. Dostoevsky's experience of imprisonment

3. Intertextual paradox of setting: Notes from the House of the Dead and Notes from Underground

7 Gawande, "Hellhole," 42.

8 “Отчего же это я такой?- почти со слезами спросил себя Обломов и спрятал опять голову под одеяло,-—право?” Ivan Goncharov, Oblomov, accessed February 22, 2016, http://www.klassika.ru/read.html?proza/goncharov/oblomov.txt\&page=18. 


\section{Debates on Punishment in the Mid-Nineteenth Century}

As Anna Schur shows in her excellent 2012 book on the subject, in the middle of the nineteenth century, Russian thinkers and government administrators were paying close attention to emerging Western theories and practices of punishment. These developments are highly relevant to a reading of Dostoevsky's works relating to problems of justice, crime, and punishment, not to mention his own experience of prison and exile. By deemphasizing corporal punishment in favor of incarceration regimes, the Russian Criminal Code of 1845 aimed to reduce arbitrariness in punishment. ${ }^{9}$ Here lies what will be one important theme for Dostoevsky: the contrast between direct human physical contact (whether violent or tender), on the one hand, and abstract social systems, on the other. In Notes from the House of the Dead, Dostoevsky offers literal depictions of both corporal punishment and the physical structures of incarceration. In Notes from Underground, I will argue, he addresses the issues of punishment in enigmatic, figurative ways that relate to the work's central problem of solipsism, using the master spatial metaphor of solitary confinement.

As Schur shows, correctional impulses were at work in the establishment of punitive solitary confinement by Western reformers, reflecting the influence of the evangelical tradition. According to the strict isolation of the "separate" or "silent" regime, prisoners were locked in a solitary cell with a Bible and other edifying texts. The point was to nurture reflection on their misdeeds, to spark moral reform from within and bring about, in the words of David Copperfield in 1850, "the reduction of prisoners to a wholesome state of mind, leading to sincere contrition and repentance." ${ }^{10}$ Schur notes that Dostoevsky would undoubtedly have been aware of a detailed article on the subject of Western penal practices by N. G. Frolov, published in Sovremennik in $1847 .{ }^{11}$ As can be the case, optimistic and ambitious social reform led to unexpected consequences. Dickens directs his satire at the system's ineffectualness-prisoners are not reformed. The model prisoner Uriah Heep, ensconced in his comfortable solitary cell, learns only a new vocabulary of piety to mask his unchanging

9 Anna Schur, Wages of Evil: Dostoevsky and Punishment (Evanston, IL: Northwestern University Press, 2012), 83.

10 Charles Dickens, David Copperfield (London: Bradbury \& Evans, 1850), ch. 61, accessed February22,2016,http://etc.usf.edu/lit2go/166/david-copperfield/3188/chapter-61-i-amshown-two-interesting-penitents/.

11 Schur, Wages of Evil, 85. 
hypocritical and villainous character. Responding to a visitor's question as to whether he was comfortable in his cell: "Yes, I thank you, sir!" said Uriah Heep, "I see my follies, now, sir. That's what makes me comfortable." ${ }^{12}$ But the system was not merely ineffectual as a means of rehabilitation. It in fact proved disastrous for inmates' physical and mental heath. Among the most frequently discussed evils of strict isolation, Schur reports, were "physical deterioration, psychological disorders, and mental disturbances"; prisoners experienced "loss of hearing, weakening of the limbs, severe depression, delusions, madness, and suicidal behavior." ${ }^{13}$ They were affected similarly regardless of their nationality, but, as Schur points out, the practice of solitary incarceration met with opposition in Russia; its reliance on the individual's moral responsibility clashed with what were assumed to be distinctly Russian values of community. ${ }^{14}$ These issues, of course, will be central to Dostoevsky's mature works, not limited to those directly addressing problems of crime and punishment.

\section{Dostoevsky's Experience of Solitary and Communal Punishment}

After his arrest in 1849 in connection with the Petrashevsky affair, Dostoevsky and the other prisoners were held in what (to any reader of Gulag memoirs, at least) seem to have been relatively benign conditions of solitary confinement in the Peter and Paul Fortress. The prisoners were visited five times a day; even General Nabokov, who headed the Commission of Inquiry, stopped by. ${ }^{15}$ Nabokov personally showed concern for the prisoners' welfare and requested that they be provided with fresh clothing and linens. ${ }^{16}$ In the summer of 1849 , M. V. Petrashevsky wrote to the Commission, asking permission for his comrades to read books and walk in the garden, "for prolonged solitary confinement ... in people with a strongly developed imagination and nervous system

12 Dickens, David Copperfield, chap. 61.

13 Schur, Wages of Evil, 86.

14 Ibid., 88.

15 Andrei M. Dostoevskii, Vospominaniia, "Kvartira piataia” (Leningrad: Izdatel'stvo pisatelei, 1930), accessed February 22, 2016, http://az.lib.ru/d/dostoewskij_a_m/text_1896_ vospominania.shtml.

16 Liudmila Saraskina, Dostoevskii: Zhizn' zamechatel'nykh liudei (Moscow: Molodaia Gvardiia, 2011), 222. 
may bring about mental collapse." ${ }^{17}$ Petrashevsky names Dostoevsky among those prisoners who could suffer deleterious effects, noting that he was on the point of hallucinating. ${ }^{18}$ Whether for this reason or some other, after two months in prison Dostoevsky was provided with books to read and given permission to take walks in the garden and, most importantly, to write. ${ }^{19}$

The effects of imprisonment on Dostoevsky and on his writing have been hotly debated. The same facts from the Peter and Paul Fortress experience are interpreted differently depending on the critic's point of view. So Schur focuses attention on a "marked decline of physical and mental health" that she finds in the letters Dostoevsky wrote from the fortress. His symptoms- "nightmares, heightened impressionability, and nervous deterioration"20 — accord with those documented among prisoners in solitary confinement. For her part, Liudmila Saraskina writes,

Unexpectedly for himself, Dostoevsky did not lose his mind or suffer spiritually. ... Eight months of incarceration, during which he had to draw exclusively on his own means, that is, on his own head ... did not come easily.... But it turned out that during the most arduous minutes of life, he, an inveterate hypochondriac with shattered nerves and a ruined digestive system, with an eternally sore throat, was able to manifest a psychological calm and a rare spiritual fortitude. ... He no longer suffered his fear of "lethargic sleep" ..., and ceased discovering in himself countless illnesses.... He dreamed "quiet, good, pleasant dreams."21

To some extent, then, it has been argued that the conditions of Dostoevsky's solitary imprisonment in the Peter and Paul Fortress served to nurture the writer's strength of character and resilience, not to mention his resources as a writerover and beyond the actual literary production of the story "A Little Hero," which he wrote in the fortress. I note again that according to the original Western model for strict correctional solitary confinement, prisoners were

17 Ibid., 229.

18 Ibid., citing Delo Petrashevtsev, ed. V. R. Leikina, E. A. Korolchuk, and V. A. Desnitskii (Moscow-Leningrad, 1937-51), 1:148-49.

19 Dostoevsky's future adversary Nikolai Chernyshevsky similarly used his time in the fortress to powerful literary effect; it was there that he wrote What Is to Be Done?, the book that Dostoevsky's narrator was to attack so pointedly in Notes from Underground.

20 Schur, Wages of Evil, 93.

21 Saraskina, Dostoevskii, 228-29. 
given paper and pen with which they were expected to record their thoughts and presumably document the salutary effects of this compulsory introspection. To readers in search of irony, therefore, Dostoevsky's experience in solitary confinement could serve as a validation of the "silent system" advocated by Western evangelical reformers. Reading, reflection, and isolation from dangerous comrades brought about positive moral effects, which were documented, to say the least, in writing.

The torments of the Siberian prison for Dostoevsky were precisely the opposite. Both in Notes from the House of the Dead and in letters he wrote upon his release, Dostoevsky repeatedly claims that his greatest suffering came from having to live constantly in a crowd of people, what his House of the Dead narrator Goryanchikov calls "compulsory communal cohabitation." (vynuzhdennoe obshchee sozhitel'stvo). ${ }^{22}$ Dostoevsky craved silence and solitude, complaining of

constant hostility and brawls on all sides ... always under guard, never alone, and this for four years without change. (To his brother Mikhail, January 30February 22, 1854) $)^{23}$

For almost five years now I have been under guard or in a crowd of people, never alone for a single hour. To be alone is a normal need, like drinking and eating; otherwise in this forced communism you become a misanthrope. The company of human beings becomes a poison and a plague, and it was this unendurable torment that caused me the most suffering for these four years. There were moments when I detested everyone who crossed my path, whether they deserved it or not, and I regarded them as thieves who had stolen my life with impunity. (To Fonvizina, February 20, 1854, from Omsk) ${ }^{24}$

The language, as so often with Dostoevsky, conveys "proof by opposite example" that conditions of solitude are salutary for an individual's spiritual and moral development. This point is not unique to the originators of the solitary incarceration regime, or to Dostoevsky. Chronicling her experience both in horrendous conditions of solitary confinement and in group incarceration, Eugenia Ginzburg writes, "Prison, and especially solitary confinement, ennobled and purified

22 F. M. Dostoevskii, Polnoe sobranie sochinenii v tridtsati tomakh, ed. V. G. Bazanov et al. (Leningrad: Nauka, 1972-90), 4:22; hereafter cited as PSS by volume and page.

23 PSS, 28:171.

24 PSS, 28:177. 
human beings, bringing to the surface their finest qualities, however deeply hidden."25 And as recently as 2012, Pussy Riot prisoner Ekaterina Samutsevich sought solitary confinement as an escape from the boring, dreary conditions of a group cell: "She had heard that if you went on hunger strike, you were transferred to solitary. She would like that." ${ }^{26}$

Dostoevsky wrote in letters immediately upon his release from prison in 1854,

I regard those four years as a time in which I was buried alive and enclosed in a coffin. I do not have the power to tell you, my friend, how horrible that time was. It was inexpressible, endless suffering, because every hour, every minute weighed upon my soul like a stone. There was never a moment during the entire 4 years when I was not aware that I was in hard labor prison. (To his brother Andrei, November 6, 1854) ${ }^{27}$

As in his thinly fictionalized memoir about the Siberian prison experience, Dostoevsky here offers the metaphor of death for communal incarceration. The external picture matches the inner one: memoirists from his prison years observe that Dostoevsky kept to himself, appeared constantly gloomy, silent, and depressed, and sought solitude. ${ }^{28}$ Interestingly, to judge by all accounts, it was precisely the conditions of solitary confinement that Dostoevsky craved while in Siberian prison - his behavior and demeanor can be interpreted as an attempt to create these conditions on a psychological level.

Any discussion of Dostoevsky's mature writing and worldview must grapple with his experience of prison and exile. The writer later claimed that living among the convict prisoners enabled him to bridge the gap between himself and the common people, contributed to the development of his philosophy of "return to the soil" (pochvennichestvo), and supported his spiritual growth. Though still dominant, this judgment has endured many challenges and refinements. Naturally, critics have focused on Notes from the House of the Dead, offering a range of interpretations, which differ primarily in the amount of weight they give to the work's fictional or nonfictional elements and the different layers in

25 Eugenia Semyonovna Ginzburg, Journey into the Whirlwind, trans. Paul Stevenson and Max Hayward (New York: Harcourt, 1995), 341.

26 Masha Gessen, Words Will Break Cement: The Passion of Pussy Riot (New York: Riverhead, 2014), 150.

27 PSS, 28:181.

28 For an excellent sampling in English, see The Dostoevsky Archive, ed. Peter Sekirin (Jefferson, NC: McFarland, 1997), 107-41. 
its narrative frame. Robert Louis Jackson offers a symbolic interpretation of the book as a narrative of resurrection; Robin Feuer Miller argues that Dostoevsky's conversion actually came before his journey to Siberia; ${ }^{29}$ Linda Ivanits focuses attention on the workings of the Christian religious imagery in the text, suggesting that Dostoevsky imbues it with ambiguities that would persist through the major writings to follow; ${ }^{30}$ Nancy Ruttenburg argues grimly that Notes from the House of the Dead, far from offering a story of redemption and reconciliation, reinforces existing class differences; ${ }^{31}$ Schur argues that the key experience for the book's narrator was his separation from the other prisoners, rather than any communion with them. ${ }^{32}$

Certainly, Goryanchikov's isolation, misanthropy, and, in fact, his death upon his release from prison seem to support this latter view. Whatever the perspective, it seems justified to note that Dostoevsky's self-segregation from the other prisoners contributed to his growth as a writer-this despite the fact that, at least officially, he was not permitted to write. He was carrying on the writer's internal work of observing the world around him and pondering the significance of what he saw: "I cannot express to you how much I suffered from not being able to write in prison. Though it is true that internally I was working intensely. Something good came of it; I could sense that" (to Maikov, January $18,1856) .{ }^{33}$

Of course, during the prison years, Dostoevsky did have access to reading material beyond the famous Bible given to him by the Decembrists' wives; during his stays in the prison hospital, a local priest brought him issues of religious journals, prison guards provided him with Dickens, and he had occasional access to newspapers. The prison doctor not only allowed Dostoevsky to write observations in what is now called his "Siberian Notebook" but also kept it safe for him when he returned to the prison barracks. ${ }^{34}$

29 Robin Feuer Miller, Dostoevsky's Unfinished Journey (New Haven, CT: Yale University Press, 2007), 28.

30 Linda Ivanits, Dostoevsky and the Russian People (Cambridge: Cambridge University Press, 2008), 31.

31 Nancy Ruttenburg, Dostoevsky's Democracy (Princeton, NJ: Princeton University Press, 2008), 89-90.

32 Schur, Wages of Evil, 13.

33 PSS, 28:209.

34 Saraskina, Dostoevskii, 261. 
Judging from all the evidence, in response to the oppressive communal conditions of his imprisonment, the writer drew on his inner resources to develop a psychological and emotional strategy of self-discipline that contributed to his development as a writer. Indeed, this condition of internal exile-let's call it solitary confinement within a crowd-was to bring extraordinary literary results. Upon his release, Dostoevsky set pen to paper and created one of the world's greatest body of works. A long period of silence sparks the urge to communicate. Here, too, the trope holds: hostages released from solitary confinement "initially ... [experience] the pure elation of being able to see and talk to people again. They can't get enough of other people, and talk almost nonstop for hours." ${ }^{35}$ Ginzburg chronicles a similar, cathartic experience upon her release into communal incarceration after two years in solitary: "At present, purified by our sufferings and full of the joy of meeting other human beings after two years of solitude, we felt like sisters in the highest sense of the word.... We chattered about everything that had happened to us." ${ }^{36}$

The literary works that emerge reflect this craving to communicate, in addition to serving as a writer's testimony to the truths observed and experienced in prison. This close relationship between imprisonment and first verbal, then literary eloquence has been particularly powerful in the Russian and Soviet context, where it has produced a major literary tradition, beginning with Notes from the House of the Dead, continuing with the works of such authors as Ginzburg, Alexander Solzhenitsyn, and Varlam Shalamov, and leading to who knows what future writing.

The Underground Man transforms this truth into fictional form, imparting to it the added force of enigma, paradox, and metaphor. A literary creature trapped in the solitary underground dreams of this moment of release: "Although we're capable of sitting silently in the underground for forty years, once we come out into the light of day and let loose, we talk and talk and talk." ${ }^{37}$ As with his experience of solitary confinement, we note in passing the parallel irony that, in the case of Dostoevsky, the Siberian prison system seems to have

35 Gawande, "Hellhole," 39.

36 Ginzburg, Journey into the Whirlwind, 264-65.

37 Fyodor Dostoevsky, Notes from Underground, trans. Boris Jakim (Grand Rapids, MI: Eerdmans, 2009), 34; PSS, 5:121. 
brought about its desired effects: the reform of a political revolutionary into a productive citizen.

\section{Paradox of Setting: Notes from the House of the Dead and Notes from Underground}

Clearly, I have been developing a paradox: a person can live in solitary confinement, even when surrounded by people. Paradox is a dominant principle in Dostoevsky's works. The most obvious example of this in Notes from Underground is its narrator's constant self-contradiction-he says one thing, and then says the opposite. But the paradoxes extend to other layers of the text, most particularly here: setting. Sometime the obvious facts - the man lives in a densely populated area (a prison, a city) — can get in the way of a truth: he is alone. Extending the sphere of study beyond a single written work can illuminate the underlying principles of how this works. Let's call it, say, a poetics of intertextual paradox.

Notes from the House of the Dead and Notes from Underground can be regarded as two integral parts of one writerly project. Introducing Alexander Petrovich Goryanchikov's manuscript, the frame editor of Notes from the House of the Dead notes that the ex-con's description of the prison was occasionally interrupted by "some other narrative, ... some strange, horrible recollections written down in uneven, convulsive handwriting, as if under some sort of compulsion." ${ }^{38}$ The identity of this set of writings has been the object of speculation among readers; might it be Goryanchikov's own confessional tale-something paralleling Shishkov's story of his murder of Akulka? Jackson, for example, parenthetically suggests that this may be "an account of his domestic tragedy." ${ }^{39}$ Gorianchikov's entire prison memoir, in that case, would represent an elaborate evasion of the most important moral point: the narrator's guilt for murdering his wife. But while keeping that possibility in mind, I will follow Jackson's other speculation that the text could be the soon-to-be-written Notes from Underground. ${ }^{40}$ Reading this way allows us to

38 Fyodor Dostoevsky, Notes from the House of the Dead, trans. Boris Jakim (Grand Rapids, MI: William B. Eerdmans, 2013), 7; PSS, 5:8.

39 Robert Louis Jackson, The Art of Dostoevsky: Deliriums and Nocturnes (Princeton, NJ: Princeton University Press, 1981), 34.

40 Ibid., 170. 
see Notes from Underground as a paired work offering the narrator's internal perspective-his introspection and focus on his own guilt and responsibility, which is lacking in Notes from the House of the Dead. Its working title- "Confession"-reinforces this point; the purpose of the underground narrator's monologue is in fact to tell the tale of his own misdeeds. Given this focus on language's ethical function, what the teller is guilty of is less important than the fact of his guilt and his need to confess it. This helps universalize the work's message, rather than deflecting it onto a safer, more tightly delineated set of concerns, such as tropes of Romantic literature, Russian debates of the 1860s, the influence of Rousseau, and so on. The narrator, named "Я," is not somebody else; rather it is "I"-me or, better, my ego alone. The prison is metaphorical—it is our human world, with our inborn guilt at its heart. To become free we must "tell our guilt." The underground is a state of self-punitive, metaphorical solitary confinement that internalizes the physical space of the prison. I am there too.

In Notes from the House of the Dead, the prison is a set of realistically described physical structures situated in a mythological landscape. The external frame narrator presents Siberia (not without irony) as a promised land, a bounteous paradise:

... one can lead a blissful existence in Siberia not only from the point of view of government service but from many other points of view as well. The climate is superb; there are many remarkably rich and hospitable merchants; there are many extremely prosperous non-indigenous inhabitants. The young ladies blossom like roses, and they're moral to the highest degree. Wild game flies about the streets and practically bumps into the hunter. Champagne is drunk in unnatural quantities. The caviar is amazing. In some places the harvest yields fifteen-fold. ... In general, it's a blessed land. ${ }^{41}$

This is a legendary, imaginary land, a paradise only visible between the palings of the prison wall and identified by Goryanchikov at the beginning of his narration as "God's world": "Sometimes you'd look through the chink in the fence at God's world: surely there must be something to see? - but the only thing you'd see would be a little corner of the sky and the high earthen ramparts, overgrown with coarse weeds, and on the ramparts the sentries would walk back and forth, day and night." ${ }^{\prime 2}$

41 Dostoevsky, Notes from the House of the Dead, 3-4; PSS, 4:5-6.

42 Ibid., 8; PSS, 4:8. 
This doubled image of the world outside prison as a paradise prompts us to view the prison metaphorically as the whole material, empirical, tangible world. From that perspective, its inhabitants are not just convicts serving time for specific crimes under the tsarist regime but, rather, humanity generally, living as we do in our self-made structures of habitat and confinement. The setting, then, offers a paradox: the "house of the dead" is actually a world teeming with life. In this metaphorical vision, the common factor shared by both worlds is the guilt of its inhabitants. From our world no one escapes alive; Goryanchikov's death, once he leaves the prison walls, is inevitable. (By the way, that famous eagle, the novel's central image of freedom, will also die; he is unable to fly.) This does not by any means disable the message of resurrection that Jackson finds in the text; it just reminds us that the message must be discovered through metaphorical readings. ${ }^{43}$

The paradox of setting challenges readers to seek freedom from our universal imprisonment. We must look within. Tolstoy's Pierre Bezukhov discovers this truth when he sits by the road and realizes that the French have no control over his immortal soul:

\footnotetext{
"Ha, ha, ha!" laughed Pierre. ... “They caught me, locked me up. They're holding me prisoner. Me who? Me? Me? — my immortal soul! Ha, ha, ha! ... Ha, ha, ha!" 44
}

True freedom is presented here as a challenge to all humanity. This does not mean that Dostoevsky (and Tolstoy) believe that political structures of oppression, including prisons, are meaningless; both of them hold passionate views on the subject. But in their great novels they tell a poetic truth, offering visions of freedom that concern all human beings, regardless of the specifics of our habitats and enclosures.

Paired with Notes from the House of the Dead, Notes from Underground offers numerous metaphorical structures with ambiguous function-shelter or imprisonment: wall, chicken coop, squalid apartment, billiards hall, brothel, Crystal Palace-all of which, not coincidentally, are man-made. The underground itself

43 I offer an expanded reading of the metaphorical setting of Notes from the House of the Dead in Carol Apollonio, "Notes from the House of the Dead: An Exercise in Spatial Reading, or Three Crowd Scenes," Rossiiskii gumanitarnyi zhurnal 3, no. 5 (2015):354-67.

44 L. N. Tolstoi, Voina i mir, Polnoe sobranie sochinenii, 90 vols., ed. V. G. Chertkov et al. (Moscow-Leningrad: Gosudarstvennoe izdatel'stvo khudozhestvennoi literatury, 192858); series 1, Proizvedeniia 12 (1933): 105-6. 
is not described as a specific physical space, rather, it serves to convey the metaphor in its broader sense. Here I take advantage of an ambitious statement that Jackson makes in his introduction to The Art of Dostoevsky: "It would appear that [Dostoevsky] insists that man is his own environment" (my emphasis). ${ }^{45}$ Indeed the reading I am offering for Notes from Underground recognizes that the boundaries between character and setting are smudged in a way that, though mind-bending, can help clarify this problem of freedom and isolation.

Why is the Underground Man the way he is? Our first answer is psychological and primitive: he was an unloved orphan, a product of the broader family breakdown in mid-century Russian society-hence the attachment disorder. His attachment disorder renders him unable to engage in healthy, loving relationships. His need to avoid human interactions predisposes him to make unhealthy choices: for example, he turns down a lucrative career offer upon graduation from high school in order to escape intimacy (specifically, the company of his schoolfellows). Similarly, he has chosen to live in a separate apartment: "I couldn't live in chambres garnies: my apartment was my solitary refuge, my shell, my lair, in which I concealed myself from all humankind." ${ }^{46}$ The Underground Man's apartment is in fact the material product of his choice to live alone; Dostoevsky's use of an organic metaphor ("my shell”) reinforces the point. He has created his own environment, it is part of him. It is his "dead house," out of which he seeks freedom in "real, living life."47

At this point it is easy to treat the Underground Man as an individual case, a troubled individual with a unique past. Such a reading lets readers off the hook too easily. Dostoevsky's character is not an individual but a representation of the ego separated from community, not due to some personal idiosyncrasy, but as the result of factors and forces that concern all humanity. In this sense he reflects his own time (1860s Russia under the reforms) and ours. These factors-social, historical, philosophical, psychological, religious, literary—have been the focus of an extraordinary body of criticism, with Notes from Underground at its center. The point of my metaphorical reading has been to show that the work's hero is not a dead, psychopathic Russian from a distant time and place, but that he is I, myself, facing problems of freedom and solipsism that are integral to the

45 Jackson, Art of Dostoevsky, 9.

46 Dostoevsky, Notes from Underground, 103; PSS, 5:168.

47 Ibid., 114; PSS, 5:176. 
human condition. Reading the work jointly with its companion, Notes from the House of the Dead, brings these problems into high relief.

Notes from the House of the Dead and Notes from Underground represent different ways of conceptualizing the problem of freedom. The former offers the external, material, literal image of the prison; the latter probes within the individual's psyche. Both convey their message through paradox: freedom and life can be found in the "house of the dead"; a free individual can be imprisoned in himself. Dostoevsky's use of "the language of freedom" is crucial; what is "will" in Notes from Underground is actually a spatialized image of "freedom" in the previous work. The word is volia. From the perspective of the House of the Dead, freedom is outside its walls, where people live " $n a$ vole":

There were men who had been totally reckless and overstepped all bounds when they were free... [ na vole] "We're lost men," they'd say. "We weren't able to live in freedom [na vole], so now we have to walk the green street." ${ }^{\text {" }}$ (my emphasis)

It is no coincidence that the Underground Man seeks freedom using the same word, volia, but it emerges into English not as "freedom," but as "will," or "free will." On the level of word choice, as with setting, the idea of freedom has moved from its spatially situated context in (outside of) the House of the Dead, inward. Often what we see in an English translation as "free will" is, in the original, "one's own will" (svoia volia) (my emphasis). For example, at the end of part 1, chapter 8:

You'll scream at me ... that no one's infringing on my free will; that they're merely busy arranging things in such a way that my will [volia] should, of its own free will [svoei sobstvennoi volei], coincide with my normal interests ... Good God, gentlemen, what sort of free will [svoia volia] can there be when it all comes down to tables and arithmetic ... ? As if that's what free will [svoia volia] is! $!^{49}$ (my emphasis)

\section{Conclusion}

In part 1 of Notes from Underground, the Underground Man diagnoses himself as a creature of acute self-consciousness, and a product of modern secular science. Dostoevsky makes him an orphan. When the Underground Man

48 Dostoevsky, Notes from the House of the Dead, 13; PSS, 4:13.

49 Dostoevsky, Notes from Underground, 30; PSS, 5:117. 
suggests that he emerged "not out of the womb of nature but out of a test tube," from here it is not even a leap, but just a little sidle over into Harlow's monkey cage, not to mention the Romanian orphans. The Underground Man is basically a lab mouse: "This test-tube man ..., genuinely regards himself not as a man but as a mouse." ${ }^{11}$ Switch the mouse for a monkey and you have a textbook specimen, the sufferer of attachment disorder, torn from his mother, and brought up by cold, hard science.

At the end of part 2, Dostoevsky's underground hero writes, "I've been feeling ashamed all the time I've been writing this story: it's not so much literature as corrective punishment." 52 Dostoevsky's works chronicle the miseries caused by the individual's separation from community. This individual, I, is both the victim and the villain in Notes from Underground-its suffering, brooding, depressed, neurotic, vengeful antihero. It suffers because it is alone, and because it is not free. This solitude, ironically, is a condition it shares with all modern humanity. By confessing his guilt in an act of writing, the individual atones for it, endures his earned punishment, and offers his text to readers as a way to overcome our shared isolation.

50 Dostoevsky, Notes from Underground, 10; PSS, 5:104.

51 Ibid.

52 Ibid., 117; PSS, 5:178. 